Tetyana Nestorenko

Berdyansk State Pedagogical University

tetyana.nestorenko@gmail.com

\title{
Olena Tokarenko
}

Berdyansk State Pedagogical University

lena1979-1@ukr.net

\section{Oleksandr Nestorenko}

Berdyansk Institute of State and Municipal Management

of the Classic Private University

oleksandr.nestorenko@ukr.net

\section{Health-resort complex development as a part of preventive medicine in the context of providing well-being}

\author{
Date of submission: 23rd of May 2017; date of acceptance: 7th of November 2017
}

JEL Classification: I18, L83, O21

Keywords: health-resort, spa, health tourism, balneotourism, model of a health-resort sector

\begin{abstract}
Health-resort complex development as a part of preventive medicine in the context of providing well-being

The present paper analyses current state of health-resort industry in Ukraine. We define possibilities for its improvement according to the foreign experience. Subject of the paper consists in setting of organizational, economic, administrative mechanisms to ensure the functioning and development of health-resort complexes. In the paper special attention is paid to the functional structure of governing health-resort organizations, structure of a resort (spa) complex, and scheme of a consumer proceeding during the consumption of resort (spa) medical service while staying at Ukrainian health resort. Some significant aspects of international experience of organizing medical spa industry are observed. The research allows to formulate recommendations aimed to enhance further innovative development of health tourism as a ground for providing well-being of people.
\end{abstract}




\section{Introduction}

The health resort (Spa) industry today has varied opportunities. It is a competitive and rapidly growing segment and one that will continue to grow. But in each country it has some own peculiarities that enhance or restrain its development.

Health spa centres play a significant role in preventive medicine and they are regarded as an important component of the overall "health market" (Santuari \& Solimene 2015).

The modern Ukrainian health-resort complex is a unique phenomenon because it represents an intersectoral complex of organisations. But nowadays some negative tendencies are on the increase, thereby restraining the development of the sector. The number of organizations that provide health and recreational services in Ukraine has fallen from 3841 units in 1990 to 1863 units - in 2015 (http://www. ukrstat.gov.ua, accessed 2016). In a period of two years (2014-2015) their incomes fell by $7 \%$, the number of employees significantly decreased by $13 \%$. A total of $16 \%$ of establishments were not open for a year. The Ukrainian health-resort industry faced some other problems, the solution of which requires detailed studies, taking into account the existing model of the health-resort industry and the possibilities for its improvement.

The purpose of the research is to investigate the peculiarities of the Ukrainian health-resort industry model and to define possibilities for its improvement according to foreign experience.

The subject of the paper is a set of organizational, economic, and administrative mechanisms to ensure the functioning and development of health resorts' complexes. The object of the research is the processes of functioning and development of health resorts' complexes as a part of preventive medicine.

Our main hypothesis is that by studying foreign experience in organizing the functioning of resorts, this will expand the possibilities for improving the existing model of the spa industry in Ukraine, and the solution of modern problems should be undertaken, taking into account its actual current strengths.

\section{Theoretical framework of the research}

There are some differences in the national terminology in the sphere of the health resort industries of different countries which, as we assume, depends on the specifics of existing models of the industry.

D. Fundeanu (2015) determines balneology tourism as one of the components of health tourism together with medical tourism, wave-therapy, hydrotherapy, spa and fitness. According to the Law of the Republic of Kazakhstan dated June 13, 2001 № 211-II “On tourist activity in the Republic of Kazakhstan”, "medical tour- 
ism is a kind of tourism, involving the combination of relaxation with access to specialized and highly specialized medical care outside of the residence" (Issyk 2015, pp. 45-47).

A. Santuari and U. Solimene define health spa centers (spa resorts) as an important component of preventive medicine (Santuari \& Solimene 2015).

The IUOTO (International Union of Official Travel Organizations) defines utilization of mineral waters and other natural resources for the provision of health as thermal tourism (IUOTO 1973). In this context Maria Zl. Stankova and Stefan Y. Kirilov point out that balneology and balneotourism are a parallel manifestation of health tourism (Stankova, Stefan \& Kirilov 2017, p. 75).

The Law of Ukraine on Tourism identifies such a type of tourism as health-improving (wellness).

According to the Law of Ukraine At Resorts (http://zakon2.rada.gov.ua/laws/ show/2026-14) resort is a mastered natural health on land that has natural medical resources necessary for their exploitation and buildings with infrastructure, used for treatment, medical rehabilitation, disease prevention and for recreation and is subject to special protection. A resort business is a set of all types of scientific, practical, and economic activities aimed at the organization and provision of treatment, medical rehabilitation, and disease prevention using natural healing resources.

Ukrainian health-resorts' organizations carry out various types of activities, such as: health-resort (medical spa) establishments, which are medical institutions; recreation organizations (boarding houses, rest homes, campsites, children's health camps); hotels and other accommodation facilities; catering organizations; tourist-excursion firms related to tourism; organizations providing recreational and entertainment services, culture and sports.

Therefore, health-resort complexes in Ukraine may be defined as an interbranch association of various organizations, specialized in the provision of health and recreational services, located in resort areas and use natural and recreational resources according to their specialization.

\section{The Ukrainian model of the health-resort sector}

The current state of development of the health-resort sector is conditioned by the transformation processes that took place in Ukraine, as well as the peculiarities of the formation and historical development of this component of the modern tourist sphere in general. In terms of the provision of resort medical resources, Ukraine occupies one of the leading places in Europe and has considerable potential in terms of recreational capacity of resorts.

In the process of the industry's formation in Ukraine, three main stages of development can be identified, which have led to the permanence and extremely deep 
roots of contemporary problems, and the last, most recent stage, on which the basis for further development is laid, began with state authorities starting the industry.

The beginning of a new stage in the development of the health-resort business can be considered the year 2000 — when, after almost four years of discussion, the Law of Ukraine "On Resorts" was first adopted. This document formulates the basic principles of modern health-and-spa activities: legislative definition of the conditions and procedures for the organization of resorts; availability of spa treatment for all citizens, primarily for disabled people, war and labor veteran, citizens affected by the Chernobyl nuclear disaster, children, women of reproductive age, gynecological diseases, tuberculosis patients and patients with trauma and diseases of the spinal cord and spine; accounting for the demands of the population for specific types of health-resort services in the development and approval of national and local programs for the development of resorts; economical and rational use of natural medical resources and ensuring their proper protection.

It is possible to determine two aspects of health resort management.

On the one hand, according to the Law of Ukraine "On resorts", spa facilities and the main type(s) of activity are administered by the Ministry of Health a medical practice; their creation takes place as prescribed in the Law of Ukraine dated 19.11.1992 № 2801-XII "Basic Laws of Ukraine on Healthcare". Bases of regulation of social relations in the organization and development of resorts are established by the Law of Ukraine dated 5.10.2000 № 2026 “On resorts”. Activity of health resorts is governed by this Law.

On the other hand, spa facilities have to comply with the Law of Ukraine "On amendments and additions to the Law of Ukraine "On Tourism", since the statistical classification of visiting recreational centers for treatment (rehabilitation) is a type of tourism. According to the Law "On the resorts" and to the Ukrainian Ministry of Health of 05.06.2005 p. № 444 "On the separation of functions to implement the articles of the Law of Ukraine "On the resorts" between the structural units of the Ministry of Health", health-resort activities are coordinated by the Ministry of Health and other branches of authority. From 2016 this part of the regulation on the activity of spa facilities was entrusted to the newly created Department of Tourism and Resorts - an independent division of the Ministry of Economic Development and Trade, established by the Ministry of Economic Development and Trade of 7.22.2016 p. № 1202 .

A more detailed functional structure of governing health-resort organizations is represented in the block diagram (Figure 1).

The organization of spa treatments are also regulated by the Ministry of Health, which includes management of the medical and social care sector with spa treatment. 
Thus, as it follows from Figure 1, health resorts activity refers both to tourism and to medicine related to tourism and recreational organizations with dominant therapeutic, preventive, and rehabilitation functions.

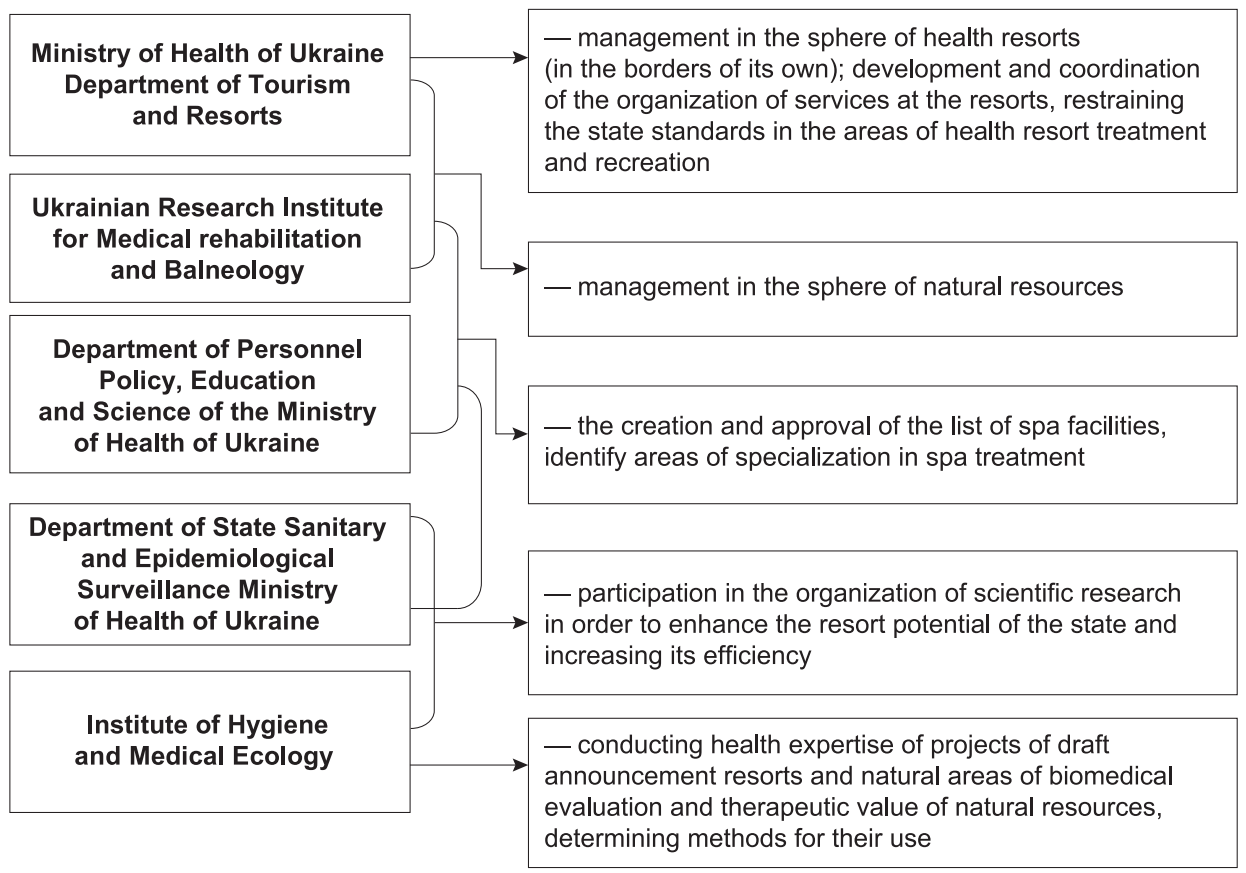

Figure 1. Functional structure of governing health-resort organizations

Source: designed by Olena Tokarenko.

Activities within the Ukrainian model of the health-resort sector are closely integrated in one economic complex as shown below (Figure 2).

Ekonomia - Wroclaw Economic Review 23/4 (2017)

(C) for this edition by CNS 


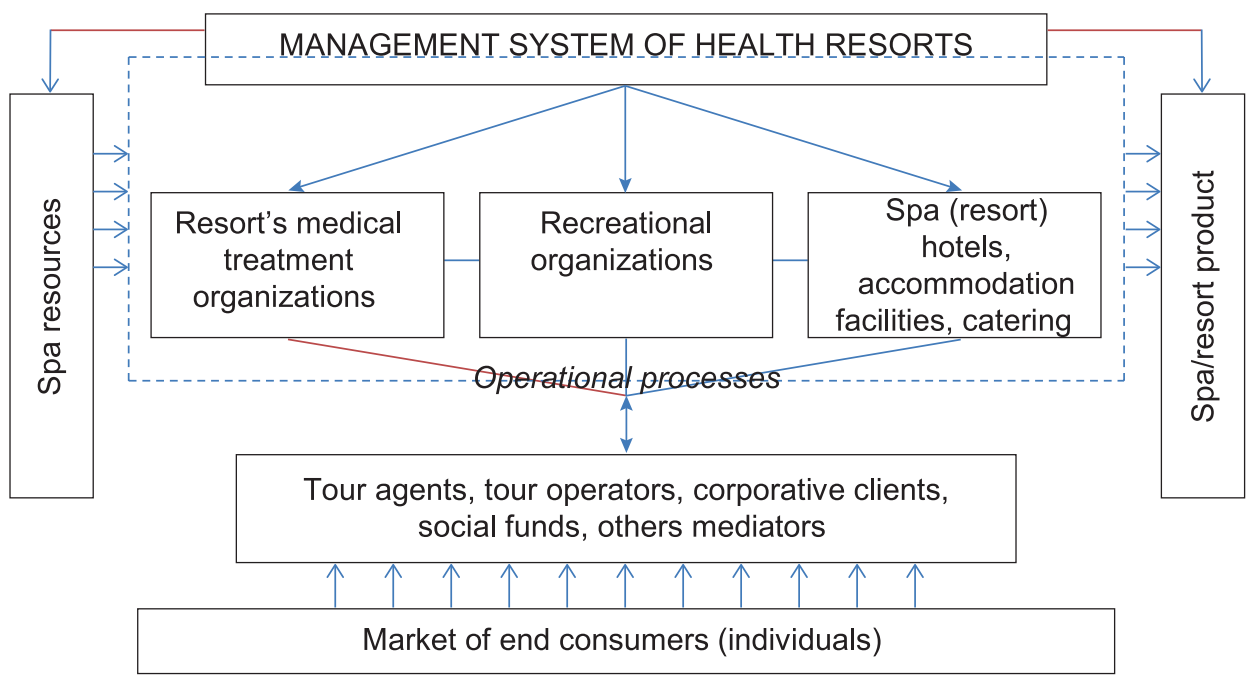

Figure 2. Structure of a resort (spa) complex

Source: designed by the authors on the basis of Ветитнев, Войнова 2014, p. 11.

The health resort management system can be divided into three levels: state level, meso-level - discussed above, and the third, corporate level of management. There are more than 100 legislative and normative acts which regulate health-resort activity in Ukraine. Seventy-five normative acts are connected with the Law of Ukraine "On resorts".

Spa resources include natural healing, as well as preformed medical factors. The first (according to the Law of Ukraine "On resorts"), include mineral and thermal waters, therapeutic mud and ozocerite, therapeutic mud, seawater, natural objects and complexes with favourable climatic conditions, suitable for use with treatment, medical rehabilitation and disease prevention.

A common activity of resorts' medical treatment and recreational organization, providing entertainment, and spa (resort) hotels, accommodation facilities and catering, together all ensure the creation of a a spa (resort) complex.

The operational processes of product creation have been determined by the methodology of resort medicine. Figure 3 represents a principal scheme of a client during the use of a spa (resort) medical service. 


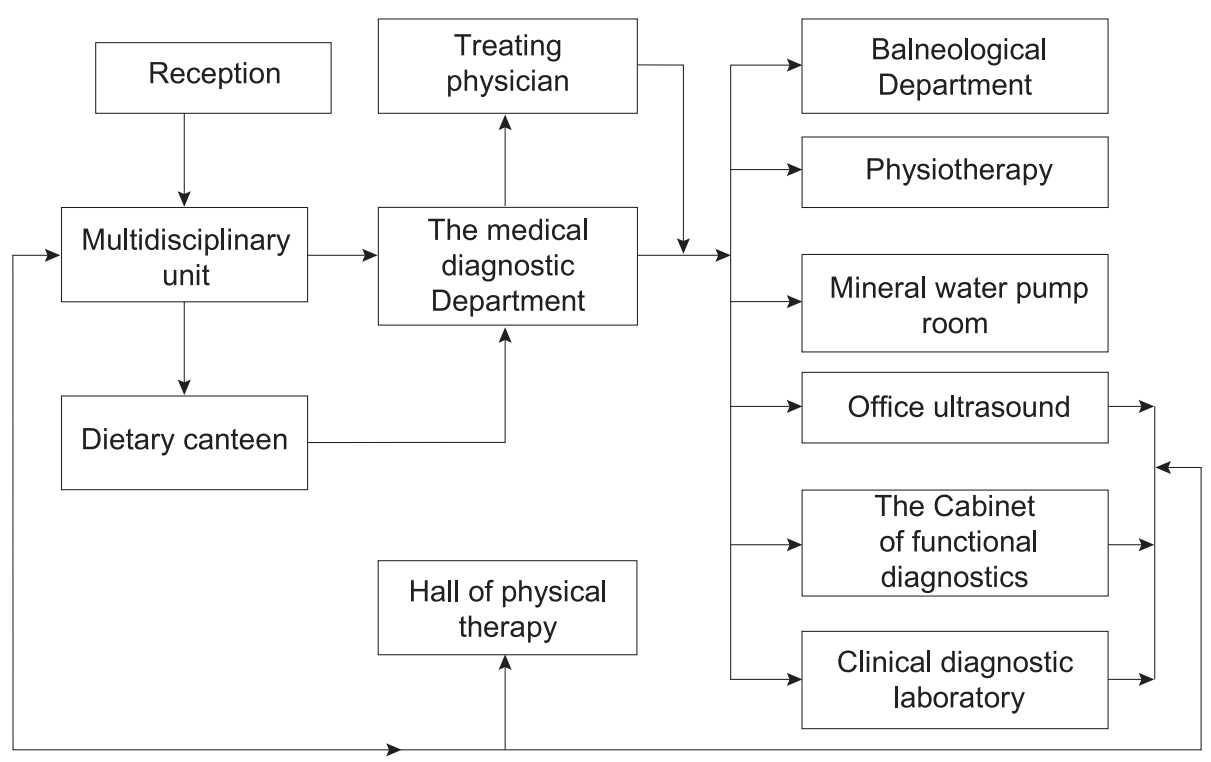

Figure 3. Principal scheme of a client during the use of a spa (resort) medical service

Source: designed by the authors on the basis of corporative internal standards of the Priazovkurort Corp. (Ukraine).

In accordance with the scheme outlined above, the client of the medical spa service goes through many stages - from diagnosis, primary examination of the attending physician - to analysis of the treatment results. At the same time, they are all included in the cost of services for the main (not concomitant) disease.

According to the classical approach such a course of treatment can take 12-24 days, where the organization of medical work of the resort has the following characteristics:

- a close relationship with previous treatment in a hospital or clinic;

- the most effective final stage of medical rehabilitation;

- a strict limitation on the composition of patients according to the medical profile of a spa;

- a strictly individual length of stay of patients in the sanatorium;

- preliminary examination of patients with the establishment of an accurate diagnosis, which eliminates or significantly reduces the diagnosis-work and creates prerequisites for the earliest possible start of spa therapy;

- availability of the necessary therapeutic and diagnostic basis, a certain profile and complex of therapeutic measures which correspond to the medical profile of the resort;

- the preventive focus of spa medicine.

In modern conditions these peculiarities may be perceived as strengths, as well as weaknesses. 


\section{International experience of organizing the medical spa industry}

Practitioners and researchers of the spa industry note a number of changes that significantly affect the formation of a modern model of preventive medicine, health-resort (spa) treatment in particular, and determine the prospects and characteristics of its further development.

At the international level, the accumulation of knowledge in this field and the exchange of experience are facilitated by the non-governmental Organization the World Federation of Hydrotherapy (FEMTEC).

A. Santuari and U. Solimene see the prospects in investments that should be undertaken to enlarge the range and variety of health provisions that individuals can find in thermal establishments. They emphasize a new role for preventative medicine to test the potential of thermal centres to match individuals' needs (Santuari \& Solimene 2015).

A. Santuari and U. Solimene assert that SPAs are no longer regarded as a social phenomenon, but they are considered to be places where to spend individual and quite short stays, during which "tourists" are also cured but especially are taken care of (Santuari \& Solimene 2015). They emphasize that whereas in the past medical SPAs used to be attended for relatively long periods of time and by sick people, nowadays hot spring resorts are visited for shorter periods of time by "health tourists" (Santuari \& Solimene 2015). We should note the same tendency in changes in the Ukrainian market as well.

We identified the following specific elements of the resort (spa) industry in some countries. French spa therapy is highly dependent on public regulations and finance. State and public bodies have a major say on the care delivered, both in nature and number, on the necessary qualifications of therapists, on a fixed 3-week duration, on hygiene and safety. At the same time, public financing of care is far more important than the contribution of complementary private health insurance and out-of-pocket payments by the patient. However, with the National Health Insurance Fund being reluctant to subsidize these new interventions, the financing scheme is yet to be worked out (Dubois 2015, p. 32).

Balneology is officially recognized in Portugal as "Medical Competence". It has a specialized commission within the Portuguese Medical Association (Cantista 2015, p. 25). Thermal programs of so-called "classic thermalism" usually take two or three weeks. Short thermalism programs ("wellness") are increasing. They maintain medical supervision and are considered a health practice. Portugal has also "social thermalism" although recently the Public Health System has cancelled the reimbursement of thermal treatments.

In Slovakia there are about 21 spas of national and international importance e.g., Piestany, Bardejov, Turcianske Teplice, Rajecke sklenne Teplice, Korytnica, 
Dudince, Kováčová, etc. Today health spa tourism forms an important part of health care and recovery mainly due to lifestyle (Talarovičová et al. 2010, p. 120). Due to Law № 538/2005 Coll. on natural healing waters, natural healing spas, spa resorts, and natural mineral waters, the use of natural healing sources in a health-resort complex is regulated by the Inspectorate of Spa Springs of the Ministry of Health.

In Kazakhstan, there are more than 50 laws and regulations on the subject of medical tourism and more than 100 regulatory legal acts on hydrotherapy. According to the Law in the Republic of Kazakhstan dated June 13, 2001 № 211-II "On tourist activity in the Republic of Kazakhstan" medical tourism is included in the tourist industry, and the government regulates this activity through licensing, standards, requirements for the contract, damages and moral damages, the establishment of legal rights and obligations, travel insurance, liability of the parties and state control in this area. According to the Strategy of the JSC "National Medical Holding" for 2008-2018 the legislation of Kazakhstan provides the possibility of paid or free treatment of citizens abroad at the expense of the republican budget (Issyk 2015, pp. 45-46).

Health or tourism cluster in some research is seen like a tool for tourism development (Fundeanu 2015, p. 220; Maraver \& Morer 2015, p. 57). Clusters are systems that include dynamic/geographic agglomerations having in the structure four categories of subsystems integrated (Fundeanu 2015, p. 220): networks of companies (leading companies, innovative firms, manufacturing, services, sales, training companies, research-development innovation, and financial institutions); facilitators (institutions, organizations involved in agreeing and cooperation actors); local government (local councils and county councils) or the Government; external connectors.

Detailed study of the structure of the model of the sanatorium-and-spa complex of Ukraine makes it possible to draw some analogies with this cluster system and assert that Ukrainian resorts have the necessary organizational and economic preconditions for transition to modernized management and operation systems.

There are some problems in health tourism development which are common for Ukraine and some other European countries:

- lack of a unified state strategic and tactical management of the health resort industry;

— inadequate organization of spa treatment and product strategy and tactics;

- lack of financial support of the state in the sphere of resort treatment of citizens;

- low solvency of the population;

— unsustainable use of natural healing resources;

- depreciation and insufficiency of the material and technical equipment of health centers;

- shortage of staff. 
All this requires the immediate development and implementation of the measures aimed at improving the legal framework of the health resort industry in Ukraine.

\section{Conclusions}

Ukraine has reach health-recreational resources as well as the relevant infrastructure, experience of health-resort treatment that provides wide possibilities for further development through such improvements as the following:

- individualization of a spa product;

— developing product strategies in order to diversify from a social product to an individual product of well-being;

— reengineering of the value chain in spa process technology;

- developing strategies at a corporate and business level in order to provide an effective model of the health resort (spa) business;

- development of training programs for medical and administrative staff and their subsequent certification, as well as introducing a program on rehabilitation medicine, balneology, and physiotherapy in the training of doctors in higher education institutions, as well as nurses in medical schools;

- preservation of the main resort areas and their natural healing resources that form the basis of the spa complex activities of a country.

Thus, resort and medical tourism can successfully take advantage of the unique resort resources for health improvement and significantly expand the scope of spa services as well as improving physical and occupational health and the quality of life.

\section{Acknowledgments}

This research was supported by the grant $\# 51601733$ of the Visegrad Fund within the framework of the Visegrad Scholarship Program - EaP.

\section{References}

Fundeanu D. (2015), "Model of health tourism development — spa tourism cluster in Romania", Management \& Marketing XIII, no. 1, pp. 216-228.

Issyk T. (2015), "Legal aspects of hydrotherapy and medical tourism in Kazakhstan (under the laws of the republic of Kazakhstan in accordance with international standards)", In Thermae and Medical Wellness Integration between Science, Economy and Tourism, 30.09.-04.10, pp. 46-51. Retrieved from https://www.femteconline.org/congresses/2015_sardinia_proceedings.pdf (access: 15.02.2017). 
Maraver F., \& Morer C. (2015), “Thermalism in Spain: What's new?”, In Thermae and Medical Wellness Integration between Science, Economy and Tourism, 30.09.-04.10, pp. 57-58. Retrieved from https://www.femteconline.org/congresses/2015_sardinia_proceedings.pdf (access: 15.02.2017).

Stanek R. (2015), "Double coincidence of wants and the essentiality of money", In Thermae and Medical Wellness Integration between Science, Economy and Tourism, 30.09.-04.10, pp. 265272. Retrieved from https://www.femteconline.org/congresses/2015_sardinia_proceedings. pdf (access: 15.02.2017).

Santuari A., \& Solimene U. (2015), "The future of thermal centres: Is a new paradigm feasible?", In Thermae and Medical Wellness Integration between Science, Economy and Tourism, 30.09.-04.10, pp. 67-69. Retrieved from https://www.femteconline.org/congresses/2015_sardinia_proceedings.pdf (access: 15.02.2017).

Stankova M., \& Kirilov S. (2017), "Improving the quality of life through balneotourism practices: The Bulgarian experience", Ekonomia - Wroclaw Economic Review 23/1, pp. 73-81.

Talarovičová V. et al. (2010), Spa Tourism Textbook - IP 2010. Comparison of Tourism Development Determinants in the European Union and Candidate Countries in the Process of Globalization on the Example of a Concrete Form of Tourism, Prešov.

Zákon z 27. októbra 2005, O prírodných liečivých vodách, prírodných liečebných kúpeloch, kúpelných miestach a prírodných minerálnych vodách a o zmene a doplnení niektorých zákonov, zbierka zákonov č. 538/2005, Čiastka 219, pp. 5010-5035.

Ветитнев А.М., Войнова Я.А. (2014), Организация санаторно-курортной деятельности: учебное пособие, Москва.

Державна служба статистики України (2015), Колективні засоби розміщування в Україні у 2014 році. Статистичний бюлетень 2015, Київ.

Державна служба статистики України (2016), Колективні засоби розміщування в Україні у 2015 році. Статистичний бюлетень 2016, Київ. 